\title{
BUDDHISM IN ASSAM: UNDERSTANDING THE HISTORY, GROWTH AND THE CURRENT TREND
}

\author{
Jharna Gogoi
}

\begin{abstract}
Assam is a north eastern state situated in the periphery of India. From time immemorial the state has absorbed multiple and diverse cultures, religions, and linguistic groups into its fold. People from varied regions have migrated into this state across different time periods. These variations provide a rich culture to the society of Assam. The people of the state follow different religions, such as Hinduism, Islam, Christianity, Buddhism etc. In this paper we will go to discuss about Buddhism-a religion that has added to the multi-cultural fabric of Assam. This paper briefly examines the history of Buddhism in Assam, the quantity of followers in the state. It also looks into the conditions that contributed in the flourishing and blooming of the religion in this land of diversity. Emphasize also is added to understand the recent trends of Buddhism in the state. How a rebel religion incorporated with Hinduism, is also a matter of discussion of the paper.
\end{abstract}

Assam is a north-eastern state located in the periphery of India-a south Asian nation-state. The state is multi-cultural, multireligious, multi-lingual, and multi-ethnic, in the true sense of the term. The society of the state is extensively heterogeneous, mixed and diverse. This diversity has been an unparellel resource for the state for generations. The larger society of the state has incorporated many religions into its fold, such as Hinduism, Islam, Christianity, Jainism and Buddhism to mention a few. With this diversity, emanates diverse stories about the state. Both in Indian 
and western literatures Assam is termed by many as a place of mystic land with the influences of black magic and tantric practices. However, in this paper I will keep the focus of the paper limited to the history, expansion and growth of one of the important religions of the region-Buddhism. At present day, it ranks fourth as a largest major religion in the world. Now a day Buddhism touches 520 million people or $7 \%$ of the global population.

\section{Methodology :}

Data can be collected both from secondary and primary sources. However, this paper largely draws the data from secondary sources, such as books, periodicals, newspapers. Some primary data were referred too from census.

Buddhism emerged as a rebel religion in India in disagreement to Hinduism. Anguttara Nikaya mentioned that after entering a person in the sangha, he became varna ${ }^{1}$-less (Singh 2009). Further, Pali canon ${ }^{2}$ gave Kshatriya higher position than Brahmana (Singh 2009). The history of Buddhism can be dated back to between $6^{\text {th }}$ and $4^{\text {th }}$ century BCE. But the religion gained substantial popularity only during the time of great king Asoka. It was the Asoka who can be given the credit of spreading Buddhism in other parts of the world, from India. Singh states,

"Maharakhita was sent to Yona (in the north- west); Majjhantika to Kashmir and Gandhara; Mahadeva to Mahishmandala (in Central India); Yona Dhammarikhita to Aparantaka in Western Malwa; Rakkhita to Vanavasi and Mahadharmmarakhita to Maharrattha (in the western Deccan); Sona and Uttara to Suvarnabhumi (perhaps in Myanmar or Southeast Asia); and Mahinda to Lanka (Sri Lanka)" (2009:351).

As Mauryan state connected with Theravada Buddhism, it was assumed that Asoka sent these Missionaries to propagate Theraveda Buddhism (Thapar 1999). After the death of Buddha, 
Buddhist councils were organized in different places of different regions. In the second Buddhist council which happened in Vaisali, first schism of Buddhism occurred. In that particular council, which was presided over by Yasa, severe differences occurred amongst the monks of Vasali, Pataliputra (Easterners) and the monks of Kausambi, Avanti (Westerners). Yasa ruled out ten laws of easterners by saying it detrimental to samgha ${ }^{3}$ (Chakravarti 2013). The easterners were dissatisfied with this decision and organized a different assembly and thus emerged the Mahasanghika. The Mahasaghikas show liberal approach to certain issues. Westerners who were known as Sthaviravadins or Theravadins sect, maintains orthodoxy in their method (Chakravarti 2013). In the development of Buddhism fourth Buddhist council take an important position. Kanishka was associated with this Buddhist council. In this Buddhist council, Buddhism was divided into two clear cut divisions-Hinayana and Mahāyāna. According to Singh (2009), it was the Mahayanist who came with these names. Mahāyāna signifies the greater vehicle and Hinayana means lesser vehicle. Mahāyāna incorporates common people while Hinayanya stayed with monastic order. Mahāyāna form of Buddhism gain popularity among masses. Scholars hold the view that Mahāyāna form of Buddhism established from Mahasanghika. Mahāyāna form of Buddhism was responsible for the incorporating of ritualistic characteristic in Buddhism. Mahayanist brought deities to worship. After the death of the Buddha to demolition of Nalanda three major Buddhism came across three important phases- Hinayana, Mahāyāna and Vajrayāna and each has their own features, ideas (Goyal 1987). Vajrayāna form of Buddhism developed later and it amalgamated with tantric elements. It included variety of God and Goddesses into their fold and started worshipping them. Orofino (2001:402) writes,

"The Buddhist Tantras, which constitute the final phase of Indian Buddhist literature, constitute a highly complex religious phenomenon, in which Mahāyāna thought coalesced 
with popular traditions and cults of ancient to form a mystical and gnostic system that was highly symbolical in character. It was called the Diamond Vehicle or Vajrayāna (from vajra, the "diamond" as symbol of the perfect and immutable nature of ultimate reality), the Mantra Vehicle or Mantrayana (from mantra, the sacred formulas that were of crucial importance in this system)."

After Vajrayāna, there were other two forms of Buddhism emerged. They are Sahajiyana and Kalacakrayana (Kalacakra or wheel of time). A south Indian prince from Kanchipuram ${ }^{4}$ Bodhidharma contributed to emerge Zen Buddhism (Guha 2019).

The history of Buddhism is very old in Assam. Literary as well as archaeological remains have sufficiently proven the significant presence of Buddhism in ancient Assam. From Kalhana's Rajatarangini we came across a Buddhist teacher, who built a Buddhist monastery for the benefit of monks which will come from foreign land. The vihara was named after Amritprabha, who was a daughter of Kamrupa king Balavarma, reign during fifth century CE. She got married to Meghavahana, the king of Kashmir. The name of the monk was stunpa and he was the guru of her father and Amritprabha took him with her (Sasananda 1986). 25 votive stupas were found in Sri Surya Pahar ${ }^{5}$. They are different in sizes and shapes. Hajo has religious significance as it popularly believed that Buddha gain parinirvana in Hajo and more than that second Buddhist council was also conducted in Hajo. This is a popular belief in Tibet, Bhutan, Ladakh and South west China (Barua 2011). The word Hajo emanated from the conjunction of two Buddhist words, 'Ha' stands for sun and 'Jo' meaning setting, which means setting the sun. Das further mentions, "This can be connected to the myth that when Buddha died, the sun over that area suddenly set" (2014:157). Hayagriva Madhava temple of Hajo is also believed to have association with Buddhism. Followers of Buddhism from neighboring states visit this temple every year. Taranath, a historian, holds Dhitika, successor of Upagupta, has significantly 
contributed in the spread of Buddhism in Assam. He further holds that Asvabhava was a preacher of Mahāyāna cult of Buddhism in this province (Baruah 2015). Choudhary (1988) mentioned that the Buddhist remains of Assam associated with Mahāyānaand Vajrayāna forms. Kamrup acquire an important place in Vajrayāna Buddhism. Gogoi put thus,

“Though Chinese pilgrim, Hiuen Tsang was surprised to see a very few Buddhist places of worship in Kamarupa, the connection of the Tantric Buddhism with this so-called land of Tantras cannot be overlooked. In fact, there are numerous evidences to sustain this point. For example, the earliest textual reference to Kamarupa as a pitha comes from the Hevajra tantra, one of the oldest Buddhist tantras composed probably in the $8^{\text {th }}$ century C.E. Again, perhapsthe most important figure of both Hindu and Buddhist Tantra in South Asia, Matsyendranatha a.k.a. Lui-pa is said to have received his esoteric knowledge in Kamarupa. Many scholars believe that the Pala kings, particularly Ratnapala and Indrapala, were patrons of the Tantric Buddhist siddhas and possibly also practitioners themselves" (2011:235).

In this Vajrayāna form of Buddhism, female deities got an important position. In the Tantric form of worship sakti is a special element and Vajrayāna incorporated sakti elements. According to Shaw, Tantra opens a path of liberation for women, who, "with their exuberant air of passion and freedom, communicate a sense of mastery and spiritual power" (Urban 2001, Shaw 1994). Locana, Mamaki, Pandara and Tara are the female goddess in Vajrayāna. Tara was most favored among them. There are various forms of Tara which are mentioned in Buddhist texts, such as Green Tara, White Tara, Ugra Tara etc. (Singh 2009). Ugra Tara is the fierce manifestation of Tara. Interestingly, Hinduism incorporates it as a deity, in the subsequent period. Regarding this Gogoi mentions,

"Most probably the concept of Goddesses worship was introduced into Vajrayanism by Padmasambhava, who was from Orissa region. He might have borrowed it only in the 
form of a concept from Brahmanical tradition and introduced goddess Tara into Vajrayanism for the first time. Here we should keep in mind that the earliest reference of Tara as goddess occurs in the context of a deity. Gradually when goddess Tara became very powerful in Tibetan Buddhism she was reintroduced and readopted in the Hindu-Tantric Pantheon, with attributes quite reflecting Buddhist Tantric development, but with modification to suit the Hindu-Tantric context" (2011:237-238).

Sahajayana form of Buddhism makes a stronghold in some parts of Assam. It was developed by sahajiya siddhas and centered on eastern India, Nepal and Tibet. A section of Sahajiya Siddhas belonged to Assam. Saraha is one of them, and he was making responsible by some scholars for the conversion of Ratnapala, a king of Kamarupa to Buddhism. Other names are Nagarjuna, Luipada etc.

According to the 2011 census of India, there is only $0.18 \%$ Buddhist population in Assam. Majority of them belong to Tai groups. These social groups are relatively new-comer and are not original inhabitants of this state. It was said that about 5000 Khamti Buddhist were migrated to this land in the second half of eighteenth century from Myanmar and after that some other Tai communities that include, the Tai-Phake, Singphos, Tai- Khamyang etc. follow the line and settled in Assam. Shyam Buddhist, who came later, settled in Jorhat, Golaghat and Sibsagar districts in the state. Other Buddhist groups like Barua, the Chakmas, and the Ryangs came from the Chittagong area of present days Bangladesh and Tibetans are newly entered in Assam, around 1959. Many of them follow the Theravada Buddhism.

Regarding the connection of Ahoms ${ }^{6}$ and Buddhism there are conflicting viewpoints occurred. Moray (2015) found that though many oppose the version of Buddhism presence in early Ahom kingdom but during translation of manuscript it was found that many Ahom prayers contains some Buddhist features. These 
prayers are still in use by the Ahoms. For instance, Ai Seng Lau is a prayer of Tai-Ahom community. In this prayer many Buddhist words were found, such as phura (Buddha), tara (teaching of the Buddha or dharma), along (Bodhisattva, previous incarnation of the Buddha), sikkya (Sakya, creator God in the Buddhist texts) and nipan (Nirvana, the state of enlightenment).

But Saikia (2006) negate the thing that Buranjis are the history of Ahoms. She (2006: 36) mentions, "Present day Tai-Ahoms claim the buranjis as their history books. The Buranjis, however, do not identify Ahom as a community in pre-colonial Assam. In fact, the term 'Ahom' is hardly ever mentioned in the text". Tai-Ahoms developed a separate religion 'Phra-Lung' for themselves as to separate themselves from the Assamese Hindus (Saikia 2006). This religion gained prominence from the time of Hiteswar Saikia ${ }^{8}$.

\section{Conclusion}

Buddhism developed in India, but it did not turn itself as a major religion, in the country. The religion however, has witnessed overwhelmed growth in the international arena. Nonetheless, it has not been able to reach to the people of India overwhelmingly. Having said that, it has given an important space to the people of this developing country, who are dubbed as untouchables, to escape from the oppressive hierarchical structure of Hinduism. It would however be incorrect to say that the religion vanished completely, and at the most it can be safely put that the religion has registered a significant decline and now only a small portion of people follow this religion, at least in the case of India. In Assam Buddhism flourished as a Vajrayāna form, where worshipping of various deity and tantra were prevalent. Assam too have not seen major growth of Buddhism in the state. It is chiefly because; the royal families were neither involved nor actively participated in popularizing the religion. With the passage of time, Assam together with different parts of the mainland India, witnessed 
striking decline of Buddhism. Presently only some social groups follow this religion in the state. The groups, who are presently following the religion in the state, have largely surfaced in eighteenth century. Though it emerged as a separate religion, but Hinduism has made an attempt to incorporate it into their fold. Hindu scripture like Purana's included Buddha into the fold of Hinduism by making him ninth incarnation of Vishnu in their incarnation system.

As we have discussed above, the number of Buddhist followers is in the sharp decline in Assam, and only a handful few remain as the Buddhist in the state. These handful people and their free choice to propagate and follow a religion need to be protected to keep the multi-cultural front of Assam truly vibrant and thriving.

\section{Notes :}

1 Varna refers to the fourfold discriminatory system of the Hindu religion.

2 Pali Canon is the standard collection of scriptures in the Theravada Buddhist tradition, as preserved in the Pali language.

3 Samgha and Sangha are used synonymously in this paper.

${ }^{4}$ Kanchipuram is presently situated in Tamil Nadu state of southern India.

${ }^{5}$ Surya Pahar is located in the Goalpara district of western Assam.

${ }^{6}$ Ahoms are a significant social group of Assam, ancestors of which ruled parts of upper Assam for no less than six hundred years. This social group migrated into the erstwhile Assam, in thirteen century. Since then the social group has completely assimilated with the local culture, language, traditions inter alia. For details see Hussain (1993).

7 Phra Lung combines of Tantric Hinduism with Thai Buddhism and local ancestor worship.

8 Former chief minister of Assam and belongs to Ahom community. 


\section{References :}

Barua, B. K. (2011): A cultural History of Assam (Early Period), Guwahati: Bina Library.

Baruah, S.L. (2015): A Comprehensive History of Assam, Delhi: Munshiram Manoharlal Publishers Pvt. Ltd.

Chakravarti, Ranabir (2013): Exploring Early India: Up to c. AD1300, Delhi: Macmillan Publishers India Ltd.

Chaudhary, P.C. (1988): Assam-Bengal Relations from the Earliest Times to the Twelfth century A.D., Delhi: Spectrum Publications Guwahati.

Das, Sneha (2014): "Engraved Histories: A Study of Legend of Naraka and Political Legitimacy in the Kamarupa Region", Proceedings of the Indian History Congress, Vol. 75, pp.153159.

Deka, Kanak Chandra (1995): "The Impact of Buddhism in Assam", Proceedings of the Indian History Congress, Vol.56, pp.140-141

Gogoi, Kakoli (2011): “Envisioning Goddess Tara: A study of the Tara Traditions in Assam", Proceedings of the Indian History Congress, Vol. 72, Part-1, pp.232-239.

Goyal, S.R.(1987): A History of Indian Buddhism, Meerut: Kushumanjali Prakashan.

Guha, Brishti (2019): "Zen, Kung Fu, and a South Indian Prince", The Wire, 09 May, (https://thewire.in/history/zen-kungfu-and-a-south-indian-prince), (Last accessed $21^{\text {st }}$ August 2019)

Hussain, Monirul (1993): The Assam Movement: Class, Ideology $\mathcal{E}$ Identity, Delhi: Manak Publications Pvt. Ltd.

Moray, Stephen (2015): "Metadata and endangered archives: lessons from the Ahom Manuscripts Project", Open Book Publishers. 
Orofino, Giacomella (2001): "The Great Wisdom Mother and the Good Tradition" in David Gordon White (ed.), Tantra in Practice, Princeton and Oxford, pp.402.

Saikia, Yasmin (2006): “Religion, Nostalgia, and Memory: Making an Ancient and Recent Tai-Ahom Identity in Assam and Thailand", The Journal of Asian Studies, Vol. 65, No. 1, pp. 33-60.

Sasanananda, S. (1986): History of Buddhism in Assam, Delhi: Bahri Publications.

Shaw, Miranda (1994): Passionate Enlightenment: Women in Tantric Buddhism, Princeton: Princeton University Press.

Singh, Upinder (2009): A History of Ancient and Early Medieval India: From the Stone Age to the $12^{\text {th }}$ Century, Delhi: Pearson.

Thapar, Ramila (1999): From Lineage to State: Social Formation in the Mid-First Millennium BC in the Ganga Valley, Delhi: Oxford University Press

Urban, Hugh B. (2001): "The Path of Power: Impurity, Kingship, and Sacrifice in Assamese Tantra", Journal of the American Academy of Religion, Vol. 69, No. 4, pp. 777-816, Dec. 